\title{
Assessment of benthic macroinvertebrates at Nile tilapia production using artificial substrate samplers
}

\author{
M. S. G. Moura e Silva ${ }^{a}$, T. S. Graciano ${ }^{b}$, M. E. Losekann ${ }^{a}$ and A. J. B. Luiz ${ }^{a}$ \\ aEMBRAPA Environment, Rodovia SP 340, Km 127,5, Tanquinho Velho, CEP 13820-000, Jaguariúna, SP, Brazil

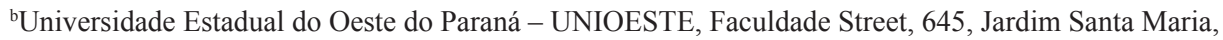 \\ CEP 85903-000, Toledo, PR, Brazil \\ *e-mail: mariana.silveira@embrapa.br
}

Received: February 19, 2015 - Accepted: May 13, 2015 - Distributed: August 31, 2016

(With 4 figures)

\begin{abstract}
Biomonitoring is a cheap and effective tool for evaluation of water quality, and infer on the balance of aquatic ecosystems. The benthic macroinvertebrates are bioindicators sensitive to environmental changes, and can assist in detecting and preventing impacts such as organic enrichment and imbalance in the food chain. We compared the structure of benthic communities on artificial substrate samplers located in places near and far from net cages for production of Nile tilapia (Oreochromis niloticus). Samplers were manufactured with nylon net, using substrates such as crushed stone, gravel, loofah and cattail leaves. Samples were collected after 30 days of colonization, rinsed and then the specimens were identified and quantified. The following metrics were calculated: richness of Operational Taxonomic Units, Margalef richness, abundance of individuals, Shannon index and evenness index. The macrobenthic community structure was strongly modified according to the proximity of the net cages. Metrics showed significant differences $(p<0.05)$ between near and distant sites, for both periods (dry and rainy seasons). The position of the samplers significantly affected the structure of macroinvertebrate community, as near sites showed higher values for the community metrics, such as richness and diversity. Near sites presented a larger number of individuals, observed both in the dry and rainy seasons, with a predominance of Chironomidae (Diptera) in the dry season and Tubificidae (Oligochaeta) in the rainy season.
\end{abstract}

Keywords: biomonitoring, aquaculture, Oreochromis niloticus, Brazil, artificial substrate sampler.

\section{Avaliação da comunidade de macroinvertebrados bentônicos em produção de tilápia-do-Nilo com uso de coletores com substrato artificial}

\begin{abstract}
Resumo
O biomonitoramento é uma ferramenta com custo relativamente baixo e eficaz para avaliação da qualidade da água, além de inferir sobre o equilíbrio dos ecossistemas aquáticos. Os macroinvertebrados bentônicos são bioindicadores sensíveis às mudanças ambientais, e podem auxiliar na detecção e prevenção de impactos como o enriquecimento orgânico e o desequilíbrio da cadeia alimentar. Como objetivo, foi comparada a estrutura das comunidades bentônicas em coletores com substrato artificial situados em locais próximos e distantes de tanques rede para produção de tilápia do Nilo (Oreochromis niloticus). Os coletores foram fabricados com rede de náilon, utilizando os substratos brita, cascalho, bucha vegetal e folhas de taboa. Foram realizadas coletas após 30 dias de colonização. As amostras foram lavadas e os espécimes identificados e quantificados. As métricas calculadas foram: riqueza de Unidades Taxonômicas Operacionais, riqueza de Margalef, abundância de indivíduos, índice de Shannon e índice de Pielou. A estrutura da comunidade macrobentônica foi fortemente modificada de acordo com a proximidade dos tanques-rede. As métricas apresentaram diferenças significativas $(\mathrm{p}<0,05)$ entre os locais próximos e distantes, em ambos os períodos (estações seca e chuvosa). A posição dos amostradores afetou significativamente a estrutura da comunidade de macroinvertebrados, na medida em que locais próximos dos tanques rede apresentaram valores mais elevados para as métricas de comunidade, como riqueza e diversidade.Amostras próximas aos tanques rede apresentaram um maior número de indivíduos em ambas as estações do ano, com predomínio de Chironomidae (Diptera) na estação seca e Tubificidae (Oligochaeta) na estação chuvosa.
\end{abstract}

Palavras-chave: biomonitoramento, aquicultura, Oreochromis niloticus, Brasil, substrato artificial. 


\section{Introduction}

Aquaculture is the farming activity that had the highest rate of growth in recent years when compared to other categories of livestock such as pig, cow, and chicken. Besides that, it stands as one of the best alternatives to meet the growing demand for aquatic food (FAO, 2010). As the demand for fish increases, the risk of deterioration of water quality resulting from intensive production also rises. When proper management is lacking, the deterioration of water quality resulting from intensive farming can compromise the stability of the ecosystem causing disturbances to the physical and chemical environments, and changes in the structure and dynamics of biological communities, manifested by marked reduction in aquatic biodiversity. On the other hand, sometimes they can also result in increased biological richness.

Biomonitoring is widely used to evaluate water quality of rivers, lakes and ponds. However, the use of this technology to assess water quality in aquaculture is still incipient in Brazil. Benthic macroinvertebrates stand out as an important component of the substrates of rivers and lakes, playing a key role in the dynamics of nutrients, transformation of matter, and flow of energy (Silveira and Queiroz, 2006), and according to Matsumura-Tundisi (1999), aquatic invertebrates are those that best respond to changing environmental conditions.

Asaduzzaman et al. (2009) studied the effect of the addition of tilapia and substrates for periphyton development on ecology, production and economic performance in the rates of $\mathrm{C} / \mathrm{N}$, in a freshwater prawn (Macrobrachium rosenbergii) farm. The authors found that the addition of tilapia and periphyton substrates benefited shrimp production through: reduction of toxic inorganic nitrogen in the water, increasing the availability of plankton, periphyton, benthic macroinvertebrates and microorganisms, reducing the demand for additional food by tilapia, which improved survival and production, and brought economic benefits.

For the effluents produced by aquaculture to meet legal standards, especially the CONAMA Resolution 430/11 (Brasil, 2011), it is essential to adopt and implement Best
Management Practices (BPMs). Nevertheless, to comply with more environmental friendly practices, it is essential that the management of water quality can be conducted in a simple, inexpensive, quick way that offers easy access to producers, with the use of low cost equipment (Queiroz et al., 2007).

The collection of benthic organisms can be made with the use of sediment samplers such as the Ekman grab, or samplers that simulate the natural environment of bottom sediments, such as artificial substrate samplers. Artificial substrate samplers have the advantages of standardizing sampling, reducing variability and processing time, and cutting operating costs, because they are easy to make and handle, and are made with cheap materials (Gibbons et al., 1993). On the other hand, the disadvantages are: it excludes certain organisms that cannot colonize it; when placed in public sites, it is subjected to vandalism; and two trips are needed: one for installation and another for removal, which can endear a draft long-term monitoring.

Artificial substrates are mostly used in marine ecology studies (Guerra-Castro and Cruz-Motta, 2014), but freshwater studies are also found in rivers (Volkmer-Ribeiro et al., 1984), coastal lagoons (Henriques-de-Oliveira et al., 2007), inland lagoons (Strixino and Trivinho-Strixino, 2006), small dam reservoirs in the savanna ecosystem in the State of Paraíba (Souza et al., 2008) and dams (Kipper et al., 2011). However, in aquaculture there are few studies that employ biomonitoring with the use of benthic organisms.

The objective of this study was to know the composition of the assembly of benthic macroinvertebrates in sites directly and indirectly influenced by farming cages of Nile tilapia (Oreochromis niloticus), in Rio do Corvo, located at Rosana Reservoir, Paraná State, Brazil.

\section{Material and Methods}

The Rosana Reservoir (Figure 1), located on the Paranapanema River basin, was closed in November 1986 and has a flooded area of $220 \mathrm{~km}^{2}$. The axis of the dam is located between the municipalities of Diamante do Norte (PR) and

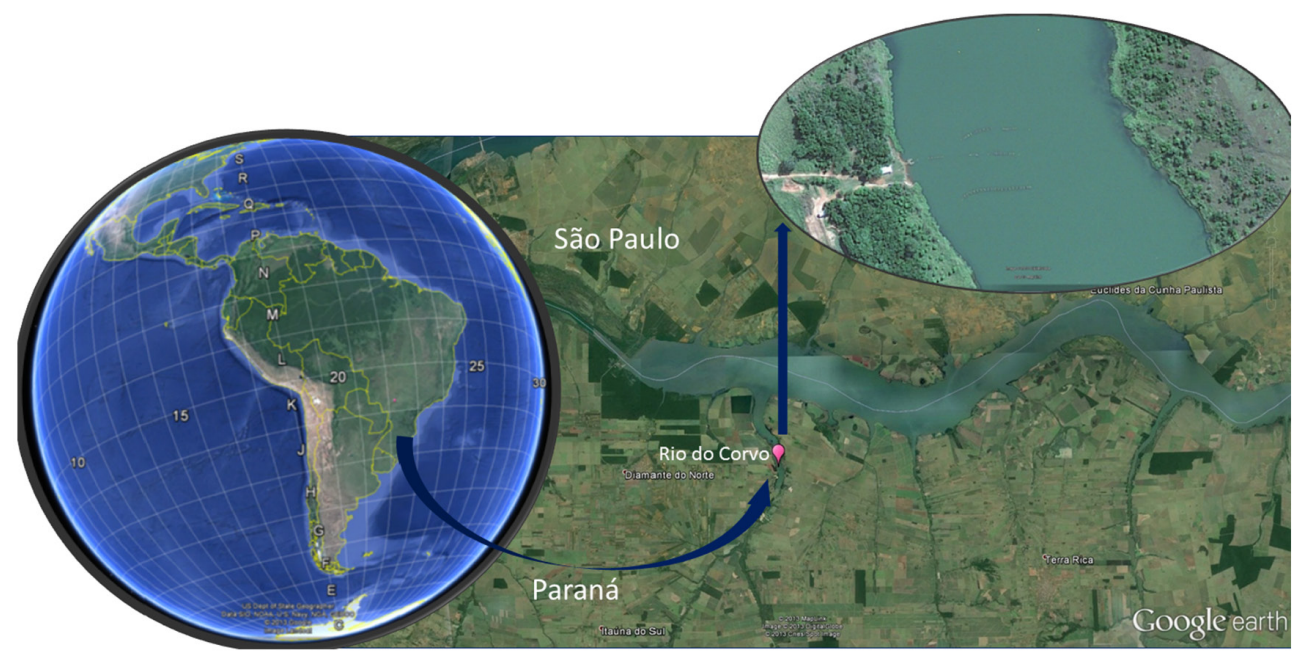

Figure 1. Study area: Rosana reservoir (Paranapanema River watershed) in Paraná State, Brazil, with sampling station in the Corvo River. Source: Google Maps (2015). 
Primavera (SP), $20 \mathrm{~km}$ from its mouth, the Paraná River. Two field campaigns at May (dry season) and November (rainy season) in 2010 were conducted at the experimental station of the Maringá State University (UEM), located in the Corvo River, where Nile tilapias are grown in cages. The geographic coordinates are: $22^{\circ} 39^{\prime} 28.03$ 'S and 52 46'51.06”O (tilapia production); and $22^{\circ} 39^{\prime} 24$ '. $4 \mathrm{~S}$ and $52^{\circ} 46^{\prime} 50^{\prime}$ '. $1 \mathrm{~W}$ (junction between Corvo river and Paranapanema river). According to the climatic classification of Köeppen, the Northwest of Paraná has climate Cfa - mesothermal, humid, without dry season and hot summers. The average temperature of the coldest month is below $18^{\circ} \mathrm{C}$ and the average temperature warmest month is above $22^{\circ} \mathrm{C}$. (Maack, 1968).

The artificial substrate samplers were manufactured with square plastic nets of five $\mathrm{kg}(32.5 \mathrm{~cm} \times 35.5 \mathrm{~cm})$, using as substrate $15 \mathrm{~g}$ of cattail, $50 \mathrm{~g}$ of loofah, and $450 \mathrm{~g}$ of crushed stone and gravel, all together in one plastic bag. Anylon thread was tied to each sampler; they were dropped into the water to reach the bottom, and the upper end of the threads were tied to a signaling floater. We evaluated three sites upstream from tilapia cages, three sites near the cages and three sites downstream from aquaculture production (Figure 2). The distance of $300 \mathrm{~m}$ from the production system is due to the buoys that limited our experimental area, from the right, left and front of the cages. Moreover, it is a safe distance as a reference point (without fish production). As the reservoir has a strong current flow close to the tilapia production area, artificial samplers were fixed at the buoys. The average depth of sites near the cages was $7.87 \mathrm{~m}$, and for distant sites the average depth was $6.23 \mathrm{~m}$. At each site three samples were evaluated, after 30 days of colonization, totaling three samples per site. The physico-chemical parameters were measured with a Horiba U10 ${ }^{\circledR}$ multiparameter probe. Samplers were removed from the reservoir after having remained submersed for 30 days, totaling 48 (16 sites in treplicate) collectors in each field campaign. After their removal, samplers were transported in plastic bags with local water to the laboratory, where they were washed under running water in steel sieves of $500 \mu \mathrm{m}$ and then stored in containers with $80 \%$ ethanol. Benthic organisms were identified at family or subfamily levels, and quantified with the aid of a stereomicroscope and taxonomic keys (Fernández and Domínguez, 2001; Mugnai et al., 2010). We calculated the following metrics for macrobenthic communities: taxa richness as Operational Taxonomic Units $\left(\mathrm{S}_{\text {OTUs }}\right)$, composed by the sum of number of identified taxa; total number of individuals, relative abundance (\%), expressed by the number of individuals of each taxon divided by the total number of individuals in the sample; Shannon diversity index, Pielou equitability index and Margalef richness index

Metrics averages were compared to assess the difference between near and far cage sites, using SAS/STAT 9.3 (SAS Institute, 2011). Randomized tests were also carried out (Manly, 2007) to evaluate the hypothesis that community metrics were different between near and far cage sites. As the number of samplers near the tank network was different from the number of samplers placed farther away, including loss of some sampler units, and due to the fact that diversity indices are dependent on the sample size, it was not possible a direct comparison of results between sites. In the case of community sampled in the dry season, three samplers were placed in ten locations per site in near

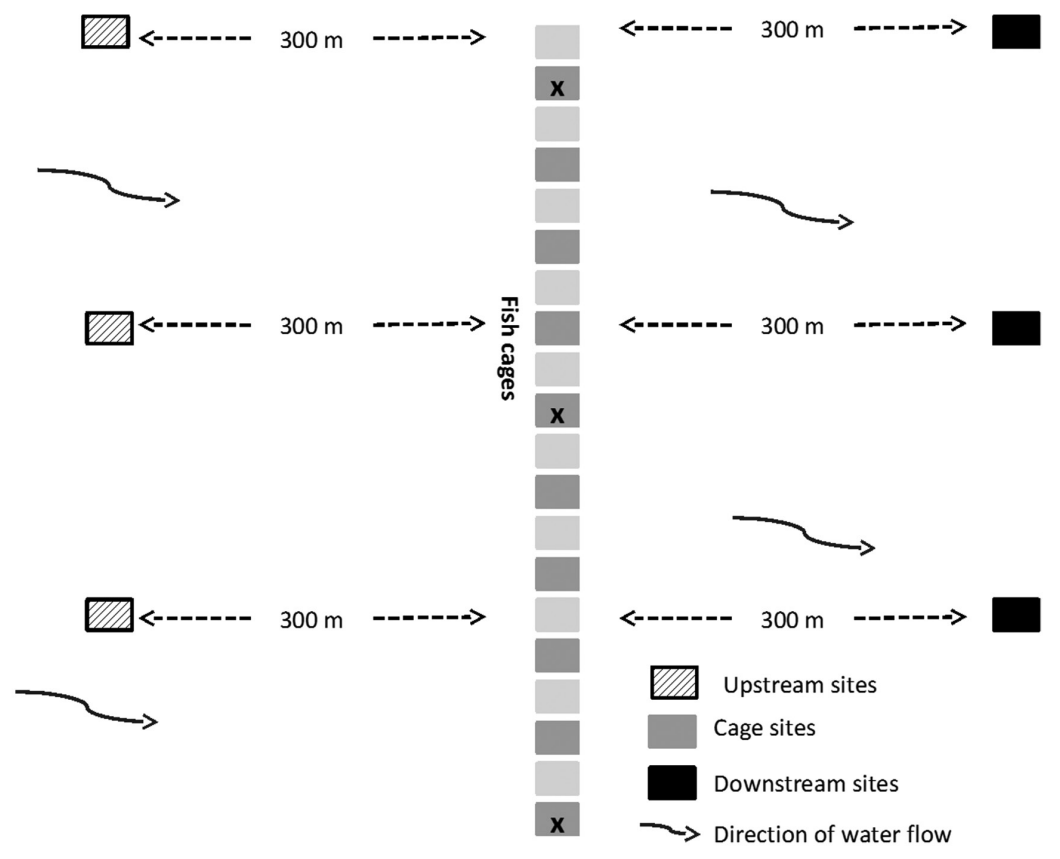

Figure 2. Schematic diagram of sampling sites distribution in the Corvo River, Paraná State, Brazil. 
to the tanks and six samplers upstream or downstream of the tanks. After the colonization period, 26 samplers remained near the tanks and 12 samplers remained distant to the tanks. To enable comparison between the indices, we used the following procedure: for sites with less number of samplers (12) (distant from cages) the value of the indices was normally calculated. For sites with greater number of samples we used the bootstrap technique, using SAS software to extract 10,000 random samples of size 12, with replacement of the original population size 26 samplers. Indices of diversity and richness were calculated for each sample. It was obtained the difference between the ratios for the two sites: near or far, resulting in 10,000 values for the difference between them. The null hypothesis was that the position of the samples relative to the tanks did not affect the results of the indices. If it should prove true, the expected average difference would be zero. Thus, from the 10.000 values obtained of the differences, we applied a t-test to test whether or not the average was equal to zero.

\section{Results}

\subsection{Physico-chemical parameters}

Table 1 shows the mean value of physicochemical parameters in two field campaigns. Except for temperature, the measured parameters did not differed between the two sampled months.

\subsection{Macroinvertebrate assessment for 30 days of colonization}

In the dry season, when comparing data of near and distant sites as concerns the relative abundance of macroinvertebrate groups, it was observed a predominance of dipteran subfamily Chironominae (44.16\%) in distant sites, and $38.85 \%$ in near sites (Figure 3 ). Considering the Chironomidae family, the most abundant subfamily was Chironominae, followed by Tanypodinae and Orthocladinae subfamilies. Class Oligochaeta was the third most frequent and most representative in numbers, in sites near the cages. The gastropods of Ancylidae also had expressive abundance with $37.9 \%$ in near sites, and $20.57 \%$ in distant sites.

During the rainy season (November), a high incidence of the subclass Oligochaeta (families Tubificidae and Glossiphonidae) was observed in sites near the cages, with about $78.31 \%$ and $15.6 \%$, respectively (Figure 4). The Ostracoda were well represented in distant sites, with $33.13 \%$.

Table 2 present the macroinvertebrate fauna observed in both field campaigns. Sites near net cages showed a greater total number of individuals than distant sites. In the rainy season, Subclass Oligochaeta was the most abundant taxon, with the presence of family Tubificidae representing $76,3 \%$ of macroinvertebrate community, unlike

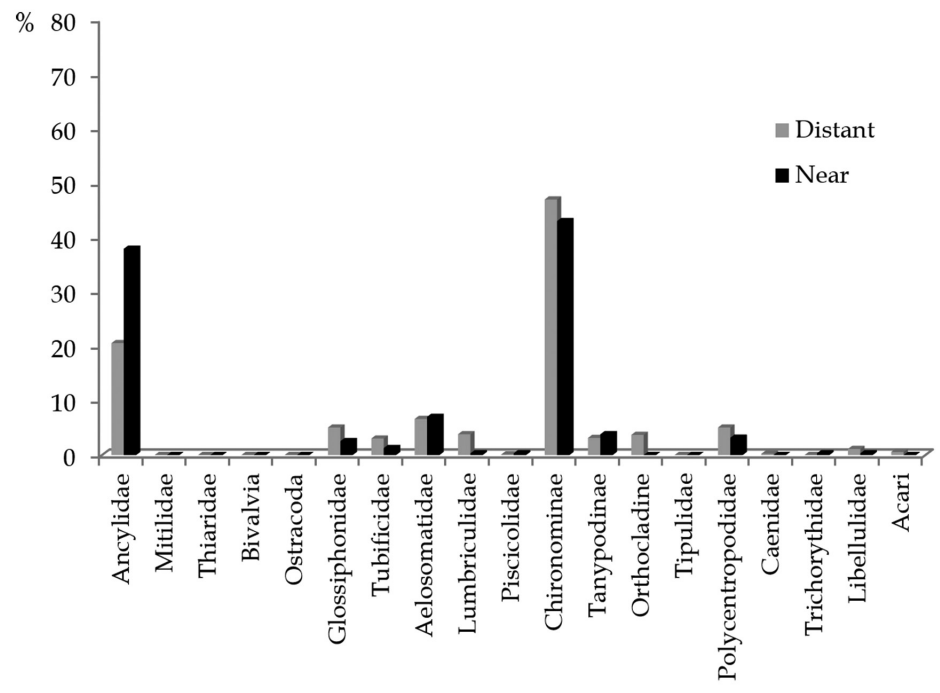

Figure 3. Relative abundance of benthic macroinvertebrates in dry season, for sites located near and distant from netcages, after 30 days of colonization in the Corvo River.

Table 1. Mean and standard deviation values for physicochemical parameters in the Corvo River in 2010.

\begin{tabular}{lcc}
\hline \multicolumn{1}{c}{ Parameter } & $\begin{array}{c}\mathbf{1}^{\text {st }} \text { sampling } \\
\text { (May }- \text { dry season) }\end{array}$ & $\begin{array}{c}\mathbf{2}^{\text {nd }} \text { sampling (November }- \text { rainy } \\
\text { season) }\end{array}$ \\
\hline Temperature $\left({ }^{\circ} \mathrm{C}\right)$ & $23.37 \pm 0.09$ & $28.26 \pm 0.06$ \\
Dissolved Oxygen $(\mathrm{mg} / \mathrm{L})$ & $8.07 \pm 0.05$ & $8.36 \pm 0.15$ \\
$\mathrm{pH}$ & $7.5 \pm 0.1$ & $7.37 \pm 0.15$ \\
Electric Conductivity $(\mathrm{mS} / \mathrm{cm})$ & $43.8 \pm 0.19$ & $46.74 \pm 0.08$ \\
\hline
\end{tabular}


Table 2. Composition and abundance of macroinvertebrate (operational taxonomic units) present at sites near and far from net cages in the Corvo River after 30 days of colonization.

\begin{tabular}{|c|c|c|c|c|}
\hline & \multicolumn{4}{|c|}{ Number of individuals } \\
\hline & \multicolumn{2}{|c|}{ Near Sites (10) } & \multicolumn{2}{|c|}{ Distant sites (6) } \\
\hline & Dry season & Rainy season & Dry season & Rainy season \\
\hline Ancylidae & 183 & 98 & 119 & 23 \\
\hline Mytilidae & 0 & 8 & 0 & 0 \\
\hline Thiaridae & 0 & 30 & 0 & 19 \\
\hline Bivalvia NI* & 0 & 26 & 0 & 1 \\
\hline Ostracoda & 0 & 0 & 0 & 221 \\
\hline Glossiphonidae & 45 & 388 & 8 & 98 \\
\hline Tubificidae & 27 & 1899 & 4 & 250 \\
\hline Aelosomatidae & 59 & 0 & 22 & 0 \\
\hline Lumbriculidae & 34 & 0 & 1 & 0 \\
\hline Piscicolidae & 1 & 3 & 1 & 0 \\
\hline Chironomidae & 479 & 28 & 147 & 65 \\
\hline Tipulidae & 0 & 6 & 0 & 8 \\
\hline Polycentropodidae & 45 & 7 & 10 & 3 \\
\hline Caenidae & 2 & 0 & 0 & 0 \\
\hline Trichorythidae & 0 & 0 & 1 & 0 \\
\hline Libellulidae & 10 & 0 & 1 & 0 \\
\hline Acari & 5 & 0 & 0 & 0 \\
\hline TOTAL & 890 & 2489 & 314 & 688 \\
\hline
\end{tabular}

*NI - non identified.

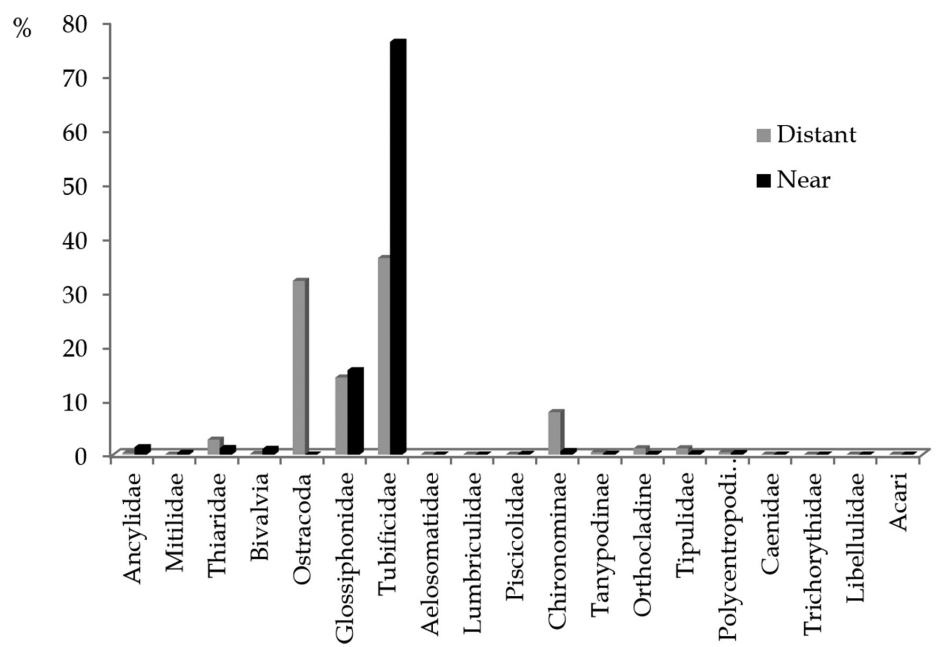

Figure 4. Relative abundance of macroinvertebrate taxa in rainy season, for sites located far from the netcages, after 30 days of colonization in the Corvo River.

the observed in the dry season period, when Aelosomatidae and Lumbriculidae families were also found (Table 2).

After Oligocheta, Chironomidae was the second major group (for all subfamilies) followed by Ancylidae and Polycentropodidae (Trichoptera).

\subsection{Metrics comparison}

Significant differences between near and far sites were observed for all the community metrics. In all cases, the null hypothesis was rejected with high significance $(\mathrm{p}<0.0001)$.
That is, the position of the samplers significantly affected the structure of macroinvertebrate community (Table 3 ). Furthermore, near sites showed higher values for these measures.

Similarly to what happened to the dry season, significant differences between near and far sites were observed for all the diversity and richness indices in the rainy season. In all cases, the null hypothesis was rejected with high significance $(p<0.0001)$. That is, the position of the samplers significantly affected the structure of macroinvertebrate 
Table 3. Margalef Richness $\left(\mathrm{S}_{\text {Margalef }}\right)$, Shannon diversity index (H') and Pielou evenness index (J) for macrobenthic community in dry season at the Corvo river and difference between indices (near - distant samplers).

\begin{tabular}{lccc}
\hline \multicolumn{1}{c}{ Indices } & Near & Distant & Difference \\
\hline Shannon $\left(\mathrm{H}^{\prime}\right)$ & 1.780 & 1.510 & $0.270^{* *}$ \\
Pielou eveness $(\mathrm{J})$ & 0.705 & 0.608 & $0.097^{* *}$ \\
Richness $\left(\mathrm{S}_{\text {Margalef }}\right)$ & 1.938 & 1.913 & $0.025^{* *}$ \\
\hline
\end{tabular}

$* * \mathrm{p}<0.0001$.

Table 4. Margalef Richness $\left(\mathrm{S}_{\text {Margalef }}\right)$, Shannon diversity index (H') and Pielou evenness index (J) for macrobenthic community in rainy season at the Corvo river and difference between indices (near - distant samplers).

\begin{tabular}{llcc}
\hline \multicolumn{1}{c}{ Indices } & Near & Distant & Difference \\
\hline Shannon $\left(\mathrm{H}^{\prime}\right)$ & 0.776 & 0.894 & $-0.118^{* *}$ \\
Pielou eveness $(\mathrm{J})$ & 0.312 & 0.467 & $-0.155^{* *}$ \\
Richness $\left(\mathrm{S}_{\text {Margalef }}\right)$ & 1.417 & 1.835 & $-0.418^{* *}$
\end{tabular}

$* * \mathrm{p}<0.0001$.

community. However, distant sites showed higher values for these measures (Table 4).

\section{Discussion}

Physicochemical parameters may influence both qualitatively and quantitatively a macrobenthic community. Changes in water quality resulting from processes of natural evolution or anthropogenic activities may cause disruption and are manifested by changes in the structure and dynamics of biological communities, as well as by the marked reduction in aquatic biodiversity. The presence of feces and feed scraps from aquaculture can increase the amount of nutrients in the sediment, mainly nitrogen and phosphorus. This contributes to the increase of the taxonomic richness and abundance of benthic macroinvertebrates. However, when the organic pollution is high, the benthic biodiversity decreases, leaving only the organisms tolerant to low concentration of dissolved oxygen in water.

Molozzi et al. (2011) observed higher taxonomic richness at the least impacted reservoir, where Chaoboridae (Diptera) represented the most abundant taxon. On the other hand, at the most impacted reservoir (urban impacts) the dominance was of Melanoides tuberculatus (Gastropoda: Thiaridae). In this study, although we have not assessed the extent of the reservoir eutrophication, the Chironomidae family was numerically important in the dry season, contributing with $52 \%$ of the fauna. In rainy season, the Chironomid larvae and pupa responded for only $2.8 \%$.

The present study showed that the relative abundance of macrobenthic taxa is different depending on the season, as we can note by greater number of Chironomidae in the dry season (May), and Tubificidae in spring (November). High densities of Oligochaeta and Chironomidae are indicative of high levels of organic matter (Lang, 1998; Hepp and Santos, 2009), as these benthic invertebrates are more tolerant to pollution (Bubinas and Jagminiené, 2001). Our data showed that these groups presented greater relative abundances in sites near the cages, with an increased total number of individuals. However, in distant sites, due to a lower relative abundance of groups considered tolerant to organic enrichment, indices for diversity and evenness indices were higher. This was reinforced by statistical analyses that proved the difference between macrobenthic communities in distant and near sites, at least for the dry period.

Jorcin and Nogueira (2008) evaluated the composition, specific richness and abundance of benthic macroinvertebrates in eight reservoirs along the Paranapanema River (São Paulo State, Brazil), as well as in its major tributaries (Taquari, Pardo and Tibagi) and in the river mouth into the Paraná River, and they also noted the predominance of Diptera (family Chironomidae). These authors also observed a relationship between abiotic factors (increased trophic, less depth) with the further development of the benthic fauna in the study area.

Other studies have reported the prevalence of the Chironomidae group in different types of environments, as reported by Lucca et al. (2010) in a tropical lake (Northeast region, Brazil), and Reis et al. (2012), who evaluated 45 lotic sites in the Peixe Angical reservoir (North region, Brazil) and observed a greater number of genera in the subfamily Chironominae, although the subfamily Orthocladiinae (considered less tolerant to organic pollution) had been prevalent (genus Cricotopus was the most abundant one).

We also found that the position of the samplers (samplers located near and far from the tanks) strongly influenced the structure of macroinvertebrate community, according to diversity and richness indices. And this occurred independently of season.

However, some facts should be highlighted: for dry season, diversity and richness indices presented higher values than the wet season. So, this indicates that the community as a whole was more balanced in the dry season, with less dominance of some taxa. In fact, as observed by relative abundances of taxa, in May (dry season) the most frequent group was Chironominae (Diptera), with about $45 \%$ of total number of individuals; and for wet season, the Tubificidae (Oligochaeta) represented about $80 \%$ of all the macroinvertebrate community.

Ogbeibu and Oribhabor (2002) also observed the dominance of Oligochaeta (Family Naididae) in a reservoir. 
In that case, Naidid oligochaetes, the dominant group in the reservoir, showed a temporal trend that was the reverse of that of Chironomidae. They were generally more prominent in the rainy season than in the dry season. Although being a different Oligochaeta family, this trend was also observed in the present study, as the Tubificidae were more abundant at the rainy season (November). Despite the recognized relationship between Tubificidae and its tolerance to high concentrations of organic matter, it cannot be said that this occurred in this study. In the present study, although the Tubificidae have been more abundant in places close to the cages (where rests of fish feed and faeces are concentrated), the dissolved oxygen values were high in both periods. The same is truth for electric conductivity, which, in case of a large resuspension, would have to show marked differences between the dry and rainy season. The greater values of diversity and richness indices in the dry season could also be explained by the stability of the water column.

Menezes and Beyruth (2003) analyzed the impacts of fish tanks on benthic communities, and observed greater percentages of Oligochaeta in the sediment close to the tanks, probably due to the increased levels of organic matter and nutrients from the fish excreta. However, the authors argue that although the increase of organic matter near the tanks network has contributed to the increase of the benthic fauna, this did not result in changes regarding water quality. So, a positive environmental impact would happen, as the increase in the benthic fauna would benefit the environment in many ways, for example, expanding the area of food fish in the natural environment. The same thing was observed by Ansah et al. (2012) for effluents of fish farms in streams in Gana. In that case, the authors classified this as a possible subsidy-stress response of macroinvertebrates.

Other studies correlate the change in macrobenthic communities structure with fish production. Camargo et al. (2011) evaluated water quality before and after the installation of a trout farm in a river in the Spanish peninsula. Results indicated an increase in the percentage of Oligochaeta and Chironomidae, and a decrease in the numbers of EPT (Ephemeroptera, Plecoptera, and Trichoptera) due to the increase in the concentration of nutrients $(\mathrm{N}$ and $\mathrm{P})$ from the effluents of fish farming. In the present study, organic nutrients were not measured, so, we cannot state that the presence of tolerant organisms to organic pollution is due to aquaculture.

The use of samplers with artificial substrate will not only house colonizations by benthic organisms, but also by the periphyton, since the materials used in the sampler (cattail leaves, loofah, crushed stone and gravel) serve as a basis for the development of periphytic algae, which indirectly also benefits herbivorous animals. This contributes to increase local biodiversity. So, it is possible that the artificial substrate sampler used in this work has contributed to enhance the diversity of benthic fauna as a result of the accumulation of feces and feed remnants in the bottom sediment, and also allowing for opportunistic species (tolerant to increased organic matter) to increase their abundance at sites near the net cages.

We highlight that there was an important difference between communities colonizing sites near and distant from the cages, and this difference was related to the dominance of groups widely known as tolerant to organic enrichment in the sites near fish cages. The seasons (dry and rainy periods) also determined the structure of macrobenthic invertebrates in artificial substrate samplers. However, long term studies (taking one year at least) and studies that can monitor physicochemical parameters more frequently are necessary to warrant a better understanding of the association between bioindicators and water quality in fish production systems. After this, the proposition of biotic indices developed for pisciculture in reservoirs would be of great value to allow monitoring of the activity and its development based on Best Management Practices.

\section{Acknowledgements}

Funds for this research were provided by Embrapa and Maringá State University. We want to thank two anonymous reviewers for their valuable comments and suggestions.

\section{References}

ANSAH, Y.B., FRIMPONG, E.A. and AMISAH, S., 2012. Biological assessment of aquaculture effects on effluent-receiving streams in ghana using structural and functional composition of fish and macroinvertebrate assemblages. Environmental Management, vol. 50, no. 1, pp. 166-180. http://dx.doi.org/10.1007/s00267012-9858-x. PMid:22555961.

ASADUZZAMAN, M., WAHAB, M.A., VERDEGEM, M.C.J., BENERJEE, S., AKTER, T., HASAN, M.M. and AZIM, M.E., 2009. Effects of addition of tilapia Oreochromis niloticus and substrates for periphyton developments on pond ecology and production in $\mathrm{C} / \mathrm{N}$-controlled freshwater prawn Macrobrachium rosenbergii farming systems. Aquaculture (Amsterdam, Netherlands), vol. 287, no. 3-4, pp. 371-380. http://dx.doi.org/10.1016/j. aquaculture.2008.11.011

BRASIL. Ministério do Meio Ambiente - MMA. Conselho Nacional do Meio Ambiente - CONAMA, 2011. Resolução $n^{\circ}$ 430, de 13 de maio de 2011. Dispõe sobre as condições e padrões de lançamento de efluentes, complementa e altera a Resolução $n^{\circ}$ 357, de 17 de março de 2005, do Conselho Nacional do Meio Ambiente-CONAMA. Diário Oficial da República Federativa do Brasil, Brasília, 16 maio. $\mathrm{n}^{\circ}$ 92, pp. 89

BUBINAS, A. and JAGMINIENÉ, I., 2001. Bioindication of ecotoxicity according to community structure of macrozoobenthic fauna. Acta Zoológica Lituanica, vol. 1, no. 1, pp. 90-99. http:// dx.doi.org/10.1080/13921657.2001.10512362.

CAMARGO, J.A., GONZALO, C. and ALONSO, A., 2011. Assessing trout farm pollution by biological metrics and indices based on aquatic macrophytes and benthic macroinvertebrates: a case study. Ecological Indicators, vol. 11, no. 3, pp. 911-917. http://dx.doi.org/10.1016/j.ecolind.2010.10.001.

FERNÁNDEZ, H.R. and DOMÍNGUEZ, E., 2001. Guía para la determinación de los artrópodos bentónicos sudamericanos. Tucumán: Facultad de Ciencias Naturales. 282 p. 
FOOD AND AGRICULTURE ORGANIZATION OF THE UNITED NATION - FAO, 2010 [viewed 07 July 2011]. Statistical databases. Rome: FAO [online]. Available from: http://www.fao.org

GIBBONS, W.N., MUNN, M.D. and PAINE, M.D., 1993. Guidelines for monitoring benthos in freshwater environments. North Vancouver: Environment Canada. 87 p. Report prepared for Environment Canada, North Vancouver, B.C. by EVS Consultants.

GOOGLE MAPS, 2015 [viewed 19 February 2015]. Rosana Reservoir: $22^{\circ} 39^{\prime} 24.4$ "S $52^{\circ} 46^{\prime} 50.1$ ' $W$ [online]. Available from: https://www.google.com/maps/place/22\%C2\%B039'24.4\%22S+ 52\%C2\%B046'50.1\%22W/@-22.6567724,-52.8156029,13528m/ data $=! 3 \mathrm{~m} 2 ! 1 \mathrm{e} 3 ! 4 \mathrm{~b} 1 ! 4 \mathrm{~m} 2 ! 3 \mathrm{~m} 1 ! 1 \mathrm{~s} 0 \times 0: 0 \times 0$

GUERRA-CASTRO, E.J. and CRUZ-MOTTA, J.J., 2014. Ecology of fouling assemblages associated with mangrove's roots: An artificial substrate for manipulative experiments. Journal of Experimental Marine Biology and Ecology, vol. 457, pp. 31-40. http://dx.doi.org/10.1016/j.jembe.2014.03.017.

HENRIQUES-DE-OLIVEIRA, C., BAPTISTA, D.F. and NESSIMIAN, J.L., 2007. Sewage input effects on macroinvertebrate community associated to Typha domingensis Pers in a coastal lagoon in Southeastern Brazil. Brazilian Journal of Biology = Revista Brasileira de Biologia, vol. 67, no. 1, pp. 73-80. http:// dx.doi.org/10.1590/S1519-69842007000100010. PMid:17505752.

HEPP, L.U. and SANTOS, S., 2009. Benthic communities of streams related to different land uses in a hydrographic basin in southern Brazil. Environmental Monitoring and Assessment, vol. 157, no. 1-4, pp. 305-318. http://dx.doi.org/10.1007/s10661-0080536-7. PMid:18843547.

JORCIN, A. and NOGUEIRA, M.G., 2008. Benthic macroinvertebrates in the Paranapanema reservoir cascade (southeast Brazil). Brazilian Journal of Biology $=$ Revista Brasileira de Biologia, vol. 68, no. 4, suppl., pp. 1013-1024. http://dx.doi.org/10.1590/ S1519-69842008000500009. PMid:19197472.

KIPPER, D., BIALETZKI, A. and SANTIN, M., 2011. Composição taxonômica da assembleia de larvas de peixes no reservatório de Rosana, Rio Paranapanema, Brasil. Biota Neotropica, vol. 11, no. 1, pp. 421-426. http://dx.doi.org/10.1590/S1676-06032011000100039.

LANG, C., 1998. Contrasting responses of oligochaetes (Annelida) and chironomids (Diptera) to the abatement of eutrophication. in Lake Neuchâtel. Aquatic Sciences, vol. 61, no. 3, pp. 206-214. http://dx.doi.org/10.1007/PL00001324.

LUCCA, J.V., PAMPLIN, P.A.Z., GESSNER, A.F., TRIVINHOSTRIXINO, S., SPADANO-ALBUQUERQUE, A.L. and ROCHA, O., 2010. Benthic macroinvertebrates of a tropical lake: Lake Caçó, MA, Brazil. Brazilian Journal of Biology $=$ Revista Brasileira de Biologia, vol. 70, no. 3, pp. 593-600. http://dx.doi.org/10.1590/ S1519-69842010000300016. PMid:20730346.

MAACK, R., 1968. Geografia física do estado do Paraná. Rio de Janeiro: José Olympio. 442 p.

MANLY, B.F.J., 2007. Randomization, Bootstrap and Monte Carlo methods in biology. 3rd ed. Boca Raton: Chapman \& Hall/ CRC Press. $455 \mathrm{p}$
MATSUMURA-TUNDISI, T., 1999. Diversidade de zooplâncton em represas do Brasil. In: R. HENRY, ed. Ecologia de reservatórios. São Paulo: FAPESP/FUNDIBIO, pp. 41-54.

MENEZES, L.C.B. and BEYRUTH, Z., 2003. Impactos da aquicultura em tanques-rede sobre a comunidade bentônica da represa de Guarapiranga - São Paulo - SP. Boletim do Instituto de Pesca, vol. 29, no. 1, pp. 77-86.

MOLOZZI, J., FRANÇAL, J. S., ARAUJO, T. L.A., VIANA, T. H., HUGHES, R. M., CALLISTO, M., 2011. Diversidade de habitats físicos e sua relação com macroinvertebrados. Iheringia, Série Zoologia, vol. 101, no. 3, pp. 191-199.

MUGNAI, R., NESSIMIAN, J.L. and BAPTISTA, D.F., 2010. Manual de Identificação de Macroinvertebrados Aquáticos do Estado do Rio de Janeiro. Rio de Janeiro: Technical Books Editora. $174 \mathrm{p}$.

OGBEIBU, A.E. and ORIBHABOR, B.J., 2002. Ecological impact of river impoundment using benthic macro-invertebrates as indicators. Water Research, vol. 36, no. 10, pp. 2427-2436. http:// dx.doi.org/10.1016/S0043-1354(01)00489-4. PMid:12153008

QUEIROZ, J.F., SILVEIRA, M.P., SITTON, M., MARIGO, A.L.S., ZAMBON, G.V., SILVA, J.R., CARVALHO, M.P. and RIBACINKO, D.B., 2007 [viewed 20 July 2012].. Coletor de Macroinvertebrados Bentônicos com Substrato Artificial para Monitoramento da Qualidade de Água em Viveiros de Produção de Tilápia. Circular Técnica [online], vol. 16, pp. 1-5. Available from: http://www.cnpma.embrapa.br/download/circular_16.pdf

REIS, E.D.A., SERPA-FILHO, A. and SILVA, V.M., 2012. Chironomidae (Diptera) do Estado do Tocantins, Brasil. EntomoBrasilis, vol. 5, no. 1, pp. 65-69. http://dx.doi.org/10.12741/ ebrasilis.v5i1.214.

SAS INSTITUTE, 2011. SAS/STAT ${ }^{\circledR} 9.3$ User's Guide. Cary: SAS Institute Inc.

SILVEIRA, M.P. and QUEIROZ, J.F., 2006. Uso de coletores com substrato artificial para monitoramento biológico de qualidade de água. Comunicado Técnico, vol. 39, pp. 1-5.

SOUZA, A.H.F.F., ABÍLIO, F.J.P. and RIBEIRO, L.L., 2008. Colonização e Sucessão Ecológica do Zoobentos em Substratos Artificiais no Açude Jatobá I, Patos - PB, Brasil. Revista de Biologia e Ciências da Terra, vol. 8, pp. 125-144.

STRIXINO, G. and TRIVINHO-STRIXINO, S., 2006. Herpobentos e haptobentos de lagoas marginais da Estação Ecológica de Jataí (Luiz Antônio, SP). In: J.E. SANTOS, J.S.R. PIRES and L.E. MOSCHINI, eds. Estudos integrados em ecossistemas: Estação Ecológica de Jataí. São Carlos: EdUFSCar. vol. 4, pp. 45-60.

VOLKMER-RIBEIRO, C., MOTHES DE MORAES, B., DE ROSA-BARBOSA, R., MANSUR, M.C.D. and VEITENHEIMERMENDES, I.L., 1984. Um estudo do bentos em raízes de Eichhornia azurea (Sw.) Kunth, do curso inferior de um rio subtropical sul-americano. Revista Brasileira de Biologia, vol. 44 , no. 2 , pp. $125-132$. 